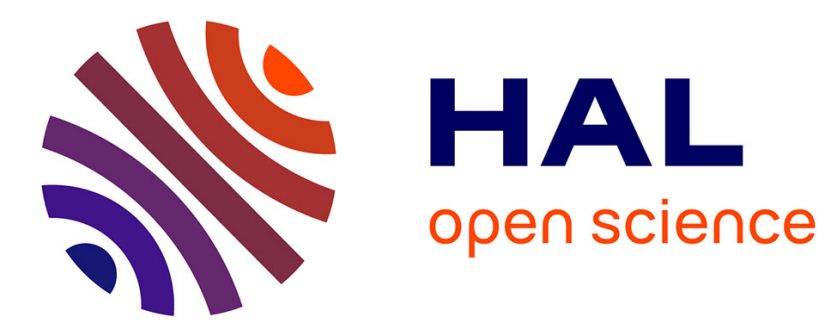

\title{
A Simple taxonomy for distributed mutual exclusion algorithms \\ Michel Raynal
}

\section{To cite this version:}

Michel Raynal. A Simple taxonomy for distributed mutual exclusion algorithms. [Research Report] RR-1362, INRIA. 1991. inria-00075198

\section{HAL Id: inria-00075198 https://hal.inria.fr/inria-00075198}

Submitted on 24 May 2006

HAL is a multi-disciplinary open access archive for the deposit and dissemination of scientific research documents, whether they are published or not. The documents may come from teaching and research institutions in France or abroad, or from public or private research centers.
L'archive ouverte pluridisciplinaire HAL, est destinée au dépôt et à la diffusion de documents scientifiques de niveau recherche, publiés ou non, émanant des établissements d'enseignement et de recherche français ou étrangers, des laboratoires publics ou privés. 


\section{Rapports de Recherche}

UNITÉ DE RECHERCHE INRIA-RENNES

\section{$N^{\circ} 1362$}

\section{Programme 3}

Intelligence artificielle, Systèmes cognitifs et Interaction homme-machine

\section{A SIMPLE TAXONOMY FOR DISTRIBUTED MUTUAL EXCLUSION ALGORITHMS}

Institut National de Recherche

en Informatique et en Automatique

Michel RAYNAL

Domaine de Voluceau

Rocquencourt

$$
\text { B.P.105 }
$$

78153 Le Chesnay Cedex

$$
\text { France }
$$

Tél.:.1) 39635511 


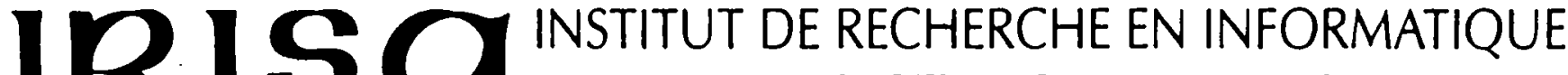 ET SYSTEMES ALEATOIRES
}

Campus Universitaire de Beaulieu 35042 - RENNES CEDEX

FRANCE

Téléphone : 99.36.20.00

Télex : UNIRISA $950473 \mathrm{~F}$

Télécopie : 99.38.38.32

\section{A simple taxonomy for distributed mutual exclusion algorithms}

\author{
Michcl RAYNAL \\ IRISA \\ C'ampus de Bcaulicu \\ 35042 Rennes-Codcx
}

Publication Interne $n^{\circ} 560-8$ pages - Novembre 1990

\section{Programme 3}

\section{Abstract}

This short paper examines the two basic principles from which distributed mulual cxclusion algorithms are designed : permission-based and tolicn-based principles. This presculation is donc in a pedagogical way and is illustrated by references to existing algorithms. licn.

licy-words: Mutual cxclusion, distributed systcm, permission, to-

\section{Résumé}

Une classification simple pour les algorithmes répartis d'cxclusion mutuclle

Celte courte nole présente les deux principes de biase a partir desqucls sout congus les algorilhmes répartis d'cxclusion mutuclle : le principe des permissions el celui du jeton.

Cette préscntation est illustréc par des références à des algorillımes cxistants. 


\title{
A simple taxonomy for clistributed mutual exclusion algorithms
}

\author{
Michel RAYNAL \\ IRISA \\ Campus de Beaulicu \\ 35042 Rennes-Cedex \\ raynal@irisa.fr
}

November 7, 1990

\begin{abstract}
This short paper examincs the hwo basic principles from which distributed mutual exclusion algorillims are designed : permission-based and token-based principles. This presentation is done in a pedagogical way and is illustrated by references to existing algorit.lims.

Key-words : Mutual exclusion, distributed system, permission, token.
\end{abstract}

\section{Introduction}

Since 1977, with Le Lann's paper[10], and 1078 will Limport's onc [9], lots of distributed algorithms have been proposed to solve the mutual exclusion problen. Only few of them were very innovative, proposing new ideas or new algorithmic techniques. The major part were designed by adapting previous and well-known solutions to specific hypotheses. The aim of this short paper is not to review all these algorithms with their underlying principles and properties (the reader may consult [16]) but to present the two simple ideas from whicl distributed mutual exclusion ate designed. These two principles define two families for such algorithms : the permission-based family $(\{2)$ and the token-based one (§3). (These two families meet when we consider that the right to entcr the critical section is managed by a central coordinator (\$4).) We limit our presentation to the principles attaclied to each of there two families.

We consider in the following a distributed system composed of $n$ siles : $P_{1}, \ldots, P_{n}$. Conmunication between processes is by messages only (there is no central memory) and transfer delays are finite but unpredictable [17]. We suppose, without loss of generality, there is one and only process per site.

\section{Permission-based algorithms}

This idea was first expressed by Ricart and Agrawala in 1981 [19] ; then it has been formalized by Sanders [21]. The idea is very simple : when a process wants to enter the critical section it asks the others for them to give it the permission to enter; and then it waits until these permissions have arrived. If a process is not interested by the critical section it scnds back its permission as soon as it receives the requests ; if it is interested a priority has to be establislicd between the two conflicting requests. In the Ricart-Agrawala's proposal a timestamp mechanism (obeying the Lamport's rule [0]) is used to associated a timestamp to each request ; as timestamp are totally ordered, conflicts are easily solved in favour of the request endowed with the lowest. limestamp.

In the Ricart-Agrawala's proposal a process nuust ask for the permissions of a statically defined set including all the other processes. Improvencnts have becn proposed concerning the management and the size of this set. In [4] a process $P_{i}$, which has reccived a pormission from $P_{j}$, dont ask $P_{j}$ anew if it was granted the critical section, and it did not reccive a request from $P_{j}$ since this granting; consequently, in this proposal, the size of the set varies dynamically for each process. (This management 
is the result of a systematic method used to ensure that a global asscrtion is always satisfied in a distributed systcm [3]). In [5] this is again inproved by climinating the necd for timestamps and using instead the acyclicity of a directed graph (the vertices are processes) representing requests priorities (the solution obtained namely the drinking philosoplsers problem-needs only bounded variables).

In the distributed database field, majority and quorum-based protocols are wcll-known techniques used to ensure consistency of updates [7,24]; morcover this enable algorithms to resist faults such as crashes or partitionnings $[2,6]$. In fact permission-based algorithuns and majority (or quorum) based protocols use the same idea : collect "enough rights" allowing to do something. So several algorithms have been proposed which differ in the size of "enough" (i.c. for cach process of the set of processes granting permissions). Mackawa, using a teclunique based on finite projective plane, reduces it to $\sqrt{n}$ [12]. Agrawal and El Abbadi reduces it to $\log (n)$ by using a trce logical st.ructurc superimposed on the distributed system [1].

To sump up : in this family the safety properly (hat states mutual exclusion is never violated) is ensured by obtaining of a sufficient number of permissions ; and the liveness property (cach request will be granted) is ensured by totally ordering the requests cither by associating a timestamp to each one or by managing a distributed acyclic directed graph, the vertices of which are the requesting processes.

\section{Token-based algorithms}

In this case the principle used is very simple : as only one process at a time can enter the critical section, the right to enter is materialized by a special object which is unique in the whole system, namely a token. As one can see the safety property is trivially cnsured as the token is unique. The only thing one has to manage is the movement of the token from one process to another one in order each request be satisfied (liveness property). At this point two possibilitics can be considered for such a movement : the perpetuum mobile and the tokc1i-asking method.

In the perpetuum mobile the token travels from one process to another one to give them the right to enter the critical section; and in order not to forget the regucst of some process the processes are put on a directed logical ring used by the tolicn. (If a process receives the token and if it is not interested in the critical section it passes it to the ncxt process along the ring). The perpetuum mobile on a ring ensures the liveness. This principle has been proposed by Le Lamn [10] and used in several algorithms [13].

In the token-asking method, the token dos not move by itself; a process willing to enter the critical section asks for the token (if it does not own it) and waits until the token arrives. Several refinements are possible. In [20] the requests of cach process are sent to all the others, each process counts the number of request received and the token carrics lite number of critical section uses per process ; there is sufficient information to ensure a movement of the token ensuring requests liveness. In [8] this principle is extended to a network with an arbitrary topology. In $[11,14,15,25]$ the requesting processes are logically structured (by the requests) as a tree and the movement of the token consists in a scquential trce traversal $[18,22]$ (a visited process is suppressed from this tree as the token leaves it).

Another distinction can be made according to the ways requesis are disseminated in the system to reach the token. [8] uses a parallel floading technique $[22] ;[14,15]$ use an underlying logical structure (a trec) to allow requests to join more quickly the tokell ; in [23] a process can use some heuristic to guess with a good likelihood where the tolien is, in order to send less requests.

\section{A special case}

In the case of a central coordinator, statically defined, the two principles meet. Processes ask only the coordinator for the permission before cntering, and this unique permission can be assimilated to a token managed by this coordinator. So this case can be seen as the separation point between the two principles. 


\section{Conclusion}

The aim of this short paper was not to precend to exhaustiveness about particular characteristics and properties of distributed mutual exclusion algorithms. (References also are not exhaustive ; refer to [16] for a more appropriate list). Its only goal was to state basic principles from which such algorithms are designed and consequently can be understood and better mastered. Such an understanding can help when, more generally, one has to implement or design distributcd control algorithms.

\section{References}

\section{References}

[1] AGRAWALA D., El ABBADI A. An efficicnt solution to the distribulcd mulual cxclusion problcm. Proc. Sth ACM Symposium on PODC, (August 1989), pp. 193-200

[2] AGRAWALA D., El ABBADI A. Exploiling logical struclures in replicaled databases. Inf. Proc. Letters, vol.33, (1990), pp. $255-260$

[3] CaRValio O.S.F., ROUCAIROL G. On the distribution of an asscrlion. Proc. 2d ACM Symposium on PODC, (1982), pp. 121-131

[4] CARVALHO O.S.F., ROUCAIROL G. On mulual cxclusion in compulcr nelworks. Comm. $\Lambda \mathrm{CM}$, vol.26,2, (1983), pp. 145-147

[5] CIIANDY K.M., MISRA J. The drinking philosophers problcm. ACM Trans, on Prog. Languages and Systems, vol.6,4, (1984), pp. 632-6.46

[6] GARCIA-MOLINA H., BARBARA D. How to assign voles in a distributed systcm. Journal of the ACM, vol.32,4, (1085), pp. $841-860$

[7] GIFFORD D.K. Weighted voting for replicated data. Proc. Tth ACM Symposium on Op.Systems Principles, (1089), pp. 150-159

[8] IIELARY J.M., PLOUZEAU N., RAY'NAL M. A distributcd algorillm for mutual exclusion in an arbitrary nctwork. The Computer Journal, vol.31,4,(1988), pp. 289-295

[9] LAMPORT L. Time, clocks and the ordering of cvents in a distribulad syslcins. Comm. ACM, vol. $21,7,(1978)$, pp. $558-565$

[10] LE LANN G. Dislributcd systems : towarls of a formal approach. IFI]' Congress, North-IIolland, (1977), pp. 155-160

[11] LYNCH N.A., TUTTLE M. Hierarchical correctness proofs for distriluted algorithms. Proc. 7th ACM Symposium on PODC, (1987), pp. 137-151

[12] MAEKAWA M. $A \sqrt{n}$ algorithm for mulual cxclusion in deccnlralizcd syslems. ACM Trans. on Comp. Systems, vol.3,2, (1985), pp. 145-159

[13] MARTIN A.J. Distributed mutual exclusion on a ring of proccssors. Science of Computer Programming, vol.5, (1985), pp. 256-270

[14] NAIMI M., TREHEL M. A distribuled algorithm for mutual exclusion based on data structures and fault tolerance. Proc. 6th Int. Phoenix IEEE Conf. on Comp. and Comm., Scottsdale, (1987), pp. 35-39

[15] RAYMOND K. A tree-based algorilhm for distribuled mulual exclusion. ACM Trans. on Comp. Systems, vol.7,1, (1989), pp. 61-77

[16] RAYNAL M. Algorithms for mutual cxclusion. The MIT Press, (1956), $107 \mathrm{p.}$ 
[17] RAYNAL M. Nelworks and distributcd compulations : concepls, tools and algorilhms. The MIT Press, (1988), $166 \mathrm{p}$.

[18] RAYNAL M., IIELARY J.M. Synchronization and control of distributcd systcms and programs. Wiley and sons, (1990), 200 p.

[19] RICART G., AGRAWALA A.K. An optimal algorilhm for mutual exclusion in computer networks. Comm. ACM, vol.24,1, (1981), pp. 9-17

[20] RICART G., AGRAWALA A.K. Author responsc to "on mutual exclusion in computer networks" by Carvalho and Roucairol. Comm. ACM, vol.26,2, (1983), pp. 147-148

[21] SANDERS B. The information structurc of distributed mutual cxclusion algorilhms. ACM Trans. on Comp. systems, vol.5,3, (1987), pp. 284-200

[22] SEGALL A. Distribuled network protocols. IEEE Trans. on Inf. Thicory, vol. IT 20,1, (1083), pp. 23-35

[23] SINGHAL M. A hcuristically-aided algorilhm for mutual cxclusion in distribulcd systenzs. IEEE Trans. on Computers, vol.38,5, (May 1989), pp. 651-662

[24] TIIOMAS R.II. A majority conscusus approach to concurrcucy control for mulliple copy databases. ACM Trans. on Database Systcms, vol.4,2, (1979), pp. 180-209

[25] Van de SNEPSCHEUT J.L. Fair mulual caclusion on a graph of processcs. Distributed Computing, vol.2, (1987), pp. 113-115 
PI 548 LES PREDICATS COLLECTIFS : UN MOYEN D'EXPRESSION DU CONTROLE DU PARALLELISME "OU" EN PROLOG

René QUINIOU, Laurent TRILLING

Septembre 1990, 34 Pages.

PI 549 NORMALISATION SOUS HYPOTHESE D'ABSENCE DE LIEN APPLICATION AU CAS NOMINAL

François DAUDE

Septembre 1990, 42 Pages.

PI 550 MULTISCALE SIGNAL PROCESSING : FROM QMF TO WAVELETS Albert BENVENISTE

Septembre 1990, 28 Pages.

PI 551 ON THE TRANSITION GRAPHS OF AUTOMATA AND GRAMMARS Didier CAUCAL, Roland MONFORT

Septembre 1990, 46 Pages.

PI 552 ERREURS DE CALCUL DES ORDINATEURS

Jocelyne ERHEL

Septembre 1990, 58 Pages.

PI 553 SEQUENTIAL FUNCTIONS

Boubakar GAMATIE, Octobre 1990, 16 Pages.

PI 554 ANALYSE DE LA FORME D'UN COEFFICIENT D'ASSOCIATION ENTRE VARIABLES QUALITATIVES

Mohamed OUALI ALLAH

Octobre 1990, 26 Pages.

PI 555 APPROXIMATION BY NONLINEAR WAVELET NETWORKS

Qinghua ZHANG, Albert BENVENISTE

Octobre 1990, 16 Pages.

PI 556 CONCEPTION ET INTEGRATION D'UN CORRELATEUR SYSTOLIQUE

Catherine DEZAN, Eric GAUTRIN, Patrice QUINTON

Novembre 1990, 16 Pages.

PI 557 VARIATIONAL APPROACH OF A MAGNETIC SHAPING PROBLEM Michel CROUZEIX

Novembre 1990, 14 Pages.

PI 558 THE DAVIDSON METHOD

Michel CROUZEIX, Bernard PHILIPPE et Miloud SADKANE

Novembre 1990, 22 Pages.

PI 559 A DISTRIBUTED SOLUTION TO THE $k$-OUT OF $M$ RESOURCES ALLOCATION PROBLEM

Michel RAYNAL

Novembre 1990, 18 Pages.

PI 560 A SIMPLE TAXONOMY FOR DISTRIBUTED MUTUAL EXCLUSION ALGORITHMS

Michel RAYNAL

Novembre 1990, 8 Pages. 


\section{Imprimé en France}

par

l'Institut National de Recherche en Informatique et en Automatique. 
ISSN 0249 - 6399 